\title{
Organizational Culture and its Impact on Employee Career Progression in Public Sector Organizations in Pakistan
}

\author{
Shuaib Ahmed \\ Institute of Business \& Technology, Karachi \\ Dr. Mohammad Asif Khan \\ Institute of Business \& Technology, Karachi
}

Zahid A. Memon

Mehran University Institute of Science, Technology and Development (MUISTD), MUET, Jamshoro

Furqan-Ul-Haq Siddiqui

Institute of Management Sciences, University of Balochistan, Quetta

\begin{abstract}
Purpose: The main objective of this paper is to examine organization culture and its impact on employee career progression in public sector organizations in Pakistan. Organization culture affects the performance and productivity of organizations in tremendous ways. The objective of the paper is to identify the relationship between culture of an organization and career progression.

Methodology/Sampling: The paper employed exploratory research method to see if organization culture has an impact on employee career progression. The data is collected from 250 employees of various public sector organizations of Pakistan. The multiple regression has been used to determine the impact of organization culture values on employees' career progression.

Findings: The study revealed that organization culture has impact on employee career progression, it plays a vital role in shaping employee career progression. Results are significant at $05 \%$ level from organization culture perspective and employee career progression perspective. Organizations that do not promote entrepreneurial and risk taking initiatives, poorly motivates employees, discourages them and consequently affects the performance of an organization \& career progression of employees.

Practical Implications: The outcome of this study provides a useful framework and importance of organization culture in Pakistan. Employees career progression can be benefited trough the findings of this study.
\end{abstract}

Keywords: Organizational culture, Career progression, employee motivation, career development, Pakistan.

JEL Classification: M100, M120, M140

\footnotetext{
* The material presented by the authors does not necessarily portray the viewpoint of the editors and the management of the Institute of Business \& Technology (IBT).

* Shuaib Ahmed: shoaib.ahmed@ibt.edu.pk

* Dr. Mohammad Asif Khan: asifmughal1973@gmail.com

* Zahid A. Memon: zahid.memon@faculty.muet.edu.pk

* Furqan-ul-Haq Siddiqui: furqan.ul.haq@gmail.com

CJMSS is published by the Institute of Business and Technology (IBT). Main Ibrahim Hydri Road, Korangi Creek, Karachi-75190, Pakistan.
} 


\section{INTRODUCTION}

Organizations are facing massive changes in technology, geographical, political, economic, legal and social dimensions. Conversely, organizational culture is considered a force underlying different elements into resilient practices. Bellou (2010) described organizational culture as all interactions of employees within an organization and its associated meaning that employees attach to those behaviors. Organization culture includes factors such as language, gestures, vision, norms, symbols, assumptions, beliefs, and habits etc. These routine practices are imparted and taught to new organizational members so that they can perceive, think and practice. Organizational culture impacts the employees, people and groups in a variety of ways by interacting with each other, stakeholders \& clients. Every organization or enterprise is affected by its culture. It has been found by several researchers such as Ogbor (2003), Schein (2004) and Alvesson (2003) that every organization has its unique culture and performance of an organization should reflect it. More recently, studies have shown how organizational performance could be traced to its culture.

Whether the discussion focuses on a bank or organizations in the public sector that exude a culture of passion or friendly customer service, it can be said without any reservations that role of culture is actually an organization's life which affects the behavior, performance, and overall effectiveness of employees' attitude. It has been indicated by a number of researchers e.g. Nongo and Ikyanyan, (2012); Nazir, (2005); Miller, (2004); Nongo,(2011); and Rasool et al. (2012) that the culture of organizations whether in the public sector or in the private sector can affect the motivation and job commitment of employees. Especially in the public sector organizations or enterprises, organizational culture can affect employees' career progression, either negatively or positively (Ejiogu, 2003; Omokhodu, 2004). The culture of an organization deserves special consideration because, as Denison (2009) rightly points out that cultural forces might have unexpected outcomes on the organization performance, if the final decisions made without noticing culture practices.

It is evident (Nazir, 2011) that the trend of administrative practices in Pakistan has become inefficient. Lack of motivation, initiative, biased decisions for solving problems, undue culture of bosses fussiness, showing stubbornness at lower levels are commonly seen. Public sector organizations are plagued with problems of productivity. There are several reasons for this, they include: (i) Fuzzy vision: when the vision of the organization and mission don't appeal employees; strategic alignment of goals are not linked as it should be; due to lack of strategic alignment, employees have no information \& knowledge in which direction organization is moving and for what. (ii) Lack of leadership skills: when members of the organization are afraid of change. A problematic culture in this regard may be characterised with the following features: fear of change, and lack of entrepreneurial spirit among managers. (iii) Discouraging culture when there is lack of shared values, everyone impose their own values, leg pulling activities, lack of belief \& trust, everyone blame on others; employees always fight and create problems but they not identify the opportunities; employees don't enjoy their work, diversity create problems, failures of employees are not tolerated. Other characteristic of the public sector organization is bureaucratic culture. A bureaucratic culture in this context is characterized by an organization with too many management layers, high boundaries between management layers, hierarchical coordination of decisions and actions, slow decision making process; too close monitoring of things and subordinates; rigid operating procedures and 
policies; and lack of initiatives; . According to Omokhudu (2004), one of the major headaches of bureaucracy, especially in the context of public sector organizations is that it is slow in responding to needed changes because of the in-built regimented requirement that brings orderliness, hierarchy, specialization, authority, etc. This requirement according to Omokhudu (2004), however, has become the excuse for public officers to perpetrate corruption, become lazy and unproductive, careless and disorderly, inefficient and unaccountable. The problems of bureaucracy in organizations, especially in developing countries, the authors poins out, include: (i) Resistance to change; (ii) Rigid adherence to rules; (iii)Reluctance to delegate authority; (v) Sycophancy; (v) Target mentality, implying difference to efficiency and purpose behind rules; (vi) Generalist or elitist orientation combined with hostility to technology; (vii) Insistence on status and prestige symbols; (viii) Overstaffing; (ix) Corruption; (x) Adherence to traditional relationships while desiring to appear modern.

In spite of the importance of organizational culture in understanding employee motivation and organizational commitment, not much research has been done on the relationship between organizational culture and employee progression in the context of public sector enterprises in Pakistan. The main aim of this paper is a theoretical evaluation of the literature on relationship between organizational culture and employee progression. Therefore the paper seeks to explore how the culture of organizations affects career development and its effect on the performance of an organization with particular attention to employees' career progression.

\subsection{STATEMENT OF THE PROBLEM}

Organizational culture affects the performance and productivity of organizations in a variety of ways. Major factors militating productivity in all the sectors is the attitude of employees to work and also discipline. There are other factors apart from these which result in the low productivity in the public sector that include inequitable salary structure, poor working and living conditions, among others, poor corporate governance and poor corporate culture are responsible for the problems faced by public sector organization. In several instances, it has been observed that most employees in these organizations do not have the knowledge of its vision, mission and strategic goals.

It is obvious that public sector is lacking the necessary skills to run organizations under its purview to achieve set goals and objectives. Secondly, many of the organizations have bureaucratic culture and do not promote entrepreneurial and risk-taking initiatives. The problem here is that the culture of bureaucracy prevalent in the public sector organizations has dire consequence on employee morale, productivity and the career progression.

\subsection{OBJECTIVE OF THE STUDY}

The purpose of this study is to achieve a theoretical understanding of how organizational culture affects career progression in public sector organizations. The study aims to examine the relationship between culture of an organization and employee's career progression. 


\section{LITERATURE REVIEW}

Organizational culture or "the culture of a group", according to Schein (2004) is "a pattern of shared basic assumptions that a group holds. Kennedy (2003) simply stated that organizational culture is "the way we do things around here." According to Bolman and Deal (2009), organizational culture is both a product and a process. As a product, it contains wisdom which learned to solve all its external problems and integration. Because of its good working it is considered valid and therefore to be taught to new employees to think \& behave in accordance with the established norms. As a process, it re-created so that newcomers employees learn the old ways and finally become teachers themselves. At its most basic, organizational culture is described as the personality of an organization, or simply as "how things are done around here."

According to Sorensen (2006) and Ogbor (2003), every organization culture has unique personality that differentiate it from others, these personality characters includes core values and beliefs, corporate ethics, \& rules of behavior. Mission statement represents the standards of corporate culture of any organization, it consist all the elements i.e. the architectural style or interior décor of offices, dress code, communication inside the organization

Wilkins, (2010), organizational culture is the interaction of employees at workplace. (Ogbor, 2003), organization culture is explained by all of the experiences, strong points, weak points, their education levels, upbringing, of employees as they are worked out in the organization. While executive leaders or founders play a large role in defining the culture of the organization by their actions and style of leadership, all employees contribute to the maintenance of the culture of the organization once it has been created Mitroff and Kilmann, (2001). Kennedy (2003), in many ways, the culture of organization affects the behaviors of its employees significantly. For instance:

- Total time period an employee works on daily, weekly, and monthly basis.

- Working environment, interaction of employees, competition level among employees, and other characteristics such as fun or hostile environment - or any other in between.

- The official dress style, attire and others i.e. casual days.

- The T\&D activities an employee receives, which help employees to perform their present and future assignment at work.

- The authority relationship between supervisors and subordinates.

- The relationship between employees and customers.

- The relationship between management, employees and external stakeholders.

- The time an employee has to go outside with other employees.

- How the employees behave with all levels of management.

Martin (2002) found out that all employees surround organization culture all the time. It is prevailing segment that actually shape employee's behavior at work environment. 


\subsection{Central Concepts of Organizational Culture}

From a theoretical perspective, understanding the major key concepts of organizational culture will help in understanding how culture affects employee career progression performance. The following seven characteristics are generally seen as constituting the central concepts of culture.

\subsubsection{Culture is the Collective Behavior of Members of a Group}

According to Pettigrew (2003), culture is sometimes described as the pragmatic when employee meets. For example, language they use when meet, the norms and routine traditions that happen, and other practices describe the behavior of the employees involved in those situations. In this way, culture is actually describes collective behaviors, norms in an environment. In the context of an organization, culture is viewed of high standards values that exists in employees. The culture of an organization or the collective behavior of its members can be supportive in achieving the mission and goals of the organization or it can be dysfunctional norms of behavior that define the culture of the organization. A norm of accountability will help make an employee to sell products in ethical way and an organization to be successful. Kennedy (2003) made the point that a collective behavior that tolerates poor performance or exhibits a lack of discipline to maintain established processes and systems will impede the success of an organization.

\subsubsection{Culture is learned}

According to Pondy, et al (1990), employee seeks to learn so that they can work and perform specific behaviors which may be of any consequences. When an employee behavior is credited, it ultimately included in organization culture. A thank gesture an employee from a higher authority motivate an employee to work harder \& it has lasting ability on culture. Employees learn culture when they interact each other at work. An applicant learn culture when he during interview session, and his or her fit within the culture.

\subsubsection{People Shape the Culture}

Pondy, et al (1990), suggested that experiences \& interactions of employees develop and shape culture of an organization. If numerous artifacts showing company's heritage \& culture and values are very clear $\&$ evident, employees will value their heritage and culture. According to Pondy, et al; the culture of an organization can be shaped in several ways, such as:

- Creating a historical foundation through providing a sense of history, communications, telling stories about founders and leaders.

- Creating an understanding of what is expected through leadership, role model examples, norms, expectations, and values.

- Creating a system where everyone feels as being a part of a team through reward systems, career management and job security, effective recruiting and staffing practices, effective socialization of new staff members, and effective training and development. 
- Encouraging interpersonal and inter-group relationships through member contact, participative decision making, inter-group coordination, and a genuine spirit of teamwork and cooperate oneness.

\subsubsection{Culture is Shared Meanings and Negotiated}

Mitroff and Kilmann (1995) argued that culture is seen as the emergent understandings created by group members as they interact with each other. Once the initial culture of the organization is created, its maintenance and sustenance depends on how the meanings embedded in the culture are shared and negotiated. For an organization's culture to be of importance the meanings involved in everyday practices must be shared. Thus, the culture of the organization is developed as employees narrate their happenings with respected to organization defined norms. As Fineman (2004) puts it, the culture of an organization has ability of helping and supporting employees and they ultimately put their efforts to prosper organization.

\subsubsection{Strong Organizational Culture Supports a Cohesive and Productive Work Environment}

Several research works have indicated that culture provides and encourages a form of stability on employees which leads to a positive and productive work environment (Lewis, 1990; Kunda, 1992; Kotter and Heskett, 1992). There exists experience involving stability, as well as a good sense involving organizational identification, given by a good organization's culture. In addition to these factors i.e. stability \& organization identity the culture can produce an awareness involving loyalty and determination among employees. Happy workers usually are actually fruitful workers. Productive workers usually are satisfied workers. Thus, Kunda (1992) suggests that it is important to explore critical aspects of the culture that actually add these qualities of into productive employees. It is the fact that with the passage of time, an organization beliefs, grow, develop beliefs, norms, and other cultural factors. Organizational leaders, including civil servants, who understand the significant of the attributes of the organization's culture such as symbols \& signs, they know how to motivate employees for creating \& developing efficient organizations which are aligned with dynamic markets.

\subsubsection{Functions of Organizational Culture}

As noted in the preceding discussion, the culture of any organization involves shared expectations, values, and attitudes that shape the behavior of the organizational members. Organizations are populated by humans - the employees who give meanings to receive meanings from their actions. It becomes necessary for organizational leaders to nurture the spirit of oneness and to develop an organizational entity that caters for the overall well-being of its employees. Kotter and Heskett (1992) identified four functions that organizational culture performs.

\subsubsection{Forming and Protecting Organizational Identify}

No organization can grow without strong commitment of its employees to the cause of the organization Silverstone, (2004). The culture of an organization has its own ability to attract, develop and keep talented people through different forms of motivation such as career 
progression or advancement Nongo, (2012); Jones, Moore and Snyder, (1988). Thus, the culture of an organization provides and encourages a form of stability. The espoused values must be collectively shared by members of the organization. In a strong culture, there is a feeling of stability, as well as a sense of organizational identity, provided by the culture of the organization.

According to Schein (2004), whenever we declare anything is "cultural" all of us indicate that it is not merely shared, but additionally firm, given it identifies the actual culture of employees group. Culture is tough to vary $\&$ change

\subsubsection{Sense of Loyalty, Harmonious, Integrative and Collective Commitment}

The grouped efforts of employees play a vital role in the success of any organization. Culture is that invisible bond of emotions and feeling that ties employees and organization into collective loyal commitment. In addition to stability and identity, the culture of an organization can generate a sense of loyalty and commitment. For instance, vision \& mission, in which the organization's code of conduct, policies ethical policies, values, and philosophies are clearly described actually provide to all employees which gives a frame of reference to abide by and remain committed for organization.

According to Ogbor (2003), this harmonious and integrative aspect of the organization is one of the major reasons why organizational theorists advocate a strong culture in an organization. A strong culture involves loyalty on the part of the employees and makes them remain committed to the goals of the organization.

\subsubsection{Socialization of Members}

The culture of an organization, according to Barley (2008), in order to promote ideal system of any organization it must have same promotions policy for every employees, remuneration and other factors related to employees. For example, many studies have shown that through the socialization process, the culture of the organization influences human resource management systems, which in turn affect employee attitudes and behaviors and organizational effectiveness. Through the socialization process, the culture of the organization contributes to organizational performance by directing employee attitudes and behaviors through core values, social cohesion, focused effort and unified, collective action in the direction of organizational missions and strategies. (Martins, 2002; Pondy, et al, 1990; Schein, 2004; Wilkins, 1989).

\subsubsection{Values and Belief Systems}

According to Deal and Kennedy (1999), the culture of an organization provides the values, beliefs, underlying assumptions, attitudes, and behaviors that are shared by the members. Shared values are plays binding role in linking all the parts of an organization together. These values are so called the identity factors by which are known by any organization. These values must be stated as both organizational (corporate) values and individual values. According to Rasool, et al (2012), every organization and every leader will have a different set of values that are appropriate to its business situation. 


\subsection{Employees' Career Progression and Organizational Culture}

As member of an organization, each employee is expected to have career goals or plans. Normally, a well planned career leads to career progression. According to Fajana (2006), career planning of employees be in matching with education, skills which are aligned with opportunities in the organization. These combinations of matching have career experts who have knowledge skills of the various jobs. This allows them to counsel individuals into jobs in which their job specifications are consistent with incumbent personnel qualifications.

Research conducted by Rasool et al, (2012) indicates that all employees who are looking for next move actually look for some meaningful \& relevant work. According to the researchers, employees can get more success in the organization if policies are employee-driven, there must be support by the culture of the organization, not employee-exclusive. In order to have implemented employee driven policies, managers have extensive knowledge about behavior of employees and these policies must be well positioned to support career development of employees.

According to Rasool, (2012), "the culture of the organization plays an important role in terms of employees' career advancement". According to Bellou (2010) there are certain employees who recognize specific organizational traits as amplifiers of job satisfaction. These amplifiers are equableness in all employees, personal growth opportunities, motivation and enthusiasm for good reputation within the organization. Aggressiveness element, seems to be job confinement element for employees. He further suggested that by incorporating these findings in organization culture overall level of job satisfaction of their employees will eventually increase. Accordingly, the organization can retain maximum no of talented employees and lesser to loose talented individuals.

A study carried out by Thomas (2011) revealed that a huge no of organizations like informal recruitment and selection processes, they discourage merit based selection process. These informal practices lead bias among existing employees. In a study carried out by Woods (2011), the organizations studied and their organizational cultures do not have correlation to celebrate diversity at workplace. He further states that strong steps should be taken to remove covert and overt practices in the organizations. From the literature the operation of promotion policies in many organizations is an area which often has unclear set of criteria attached.

In a study carried out by Bellou (2010), it was established that employees recognize certain cultural traits as job satisfaction amplifiers. These amplifiers are empowerment, professional development, skill development \& good reputation. On the other hand, organizational cultural traits such as (vision \& mission, consistency in policies, agreement, organizational learning, customer focus, seems to confine job satisfaction and the propensity for career progression.

\section{RESEARCH METHODOLOGY \& RESULTS}

An instrument was developed to test the content and validity of this research. Survey with multiple techniques was used to collect responses from employees of public sector 
organizations all over Pakistan. Random sampling has been used, sample size comprising of 250 personnel of public sector working at various positions are taken in the presence of researcher to ensure interaction and clarification (if any). Questionnaire which has been developed consists two parts. Sections A of the questionnaire contain demographic information of the respondents. However, Section B contains nineteen statements regarding organizational culture and employee career progression. After validating the instrument using SPSS 17, it has been analyzed by using frequency distribution to see how employee career progression is correlated with organizational culture. Simple linear regression has been used to see the impact of organizational cultural activities on employee career progression.

\subsection{Reliability test}

Reliability of the instrument is found to be good i.e. Cronbach's Alpha is .894 which shows that the instrument to study organizational culture and employee career progression have a good consistency.

Table 1: Reliability Statistics

\begin{tabular}{|l|l|}
\hline Cronbach's Alpha & N of Items \\
\hline .895 & 8 \\
\hline
\end{tabular}

\subsection{Descriptive Statistics}

The descriptive statistics shown in Table 2 of the instrument for employee career progression i.e. empowerment, professional development, skill development and organization culture i.e. vision \& mission, agreement, organizational learning, customer focus.

Table 2

Descriptive Statistics

\begin{tabular}{|c|c|c|c|c|c|c|c|c|c|c|c|c|c|c|c|c|c|}
\hline \multirow[t]{2}{*}{$\begin{array}{l}\text { Gend } \\
\text { er }\end{array}$} & \multirow[t]{2}{*}{$\begin{array}{l}\text { Sam } \\
\text { ple } \\
\text { Size }\end{array}$} & \multicolumn{2}{|c|}{$\begin{array}{l}\text { Empower } \\
\text { ment }\end{array}$} & \multicolumn{2}{|c|}{$\begin{array}{l}\text { Profession } \\
\text { al } \\
\text { Developme } \\
\text { nt }\end{array}$} & \multicolumn{2}{|c|}{$\begin{array}{l}\text { Skill } \\
\text { Developm } \\
\text { ent }\end{array}$} & \multicolumn{2}{|c|}{$\begin{array}{l}\text { Vision/Mi } \\
\text { ssion }\end{array}$} & \multicolumn{2}{|c|}{$\begin{array}{l}\text { Consistenc } \\
\mathrm{y} \text { in } \\
\text { Policies }\end{array}$} & \multicolumn{2}{|c|}{$\begin{array}{l}\text { Agreeme } \\
\text { nt }\end{array}$} & \multicolumn{2}{|c|}{$\begin{array}{l}\text { Organizatio } \\
\text { n Learning }\end{array}$} & \multicolumn{2}{|c|}{$\begin{array}{l}\text { Customer } \\
\text { Focus }\end{array}$} \\
\hline & & $\begin{array}{l}\text { Mea } \\
n\end{array}$ & S.D & $\begin{array}{l}\text { Mea } \\
\mathrm{n}\end{array}$ & $\begin{array}{l}\text { S. } \\
\text { D }\end{array}$ & $\begin{array}{l}\text { Mea } \\
n\end{array}$ & $\begin{array}{l}\text { S. } \\
\text { D }\end{array}$ & $\begin{array}{l}\text { Mea } \\
\mathrm{n}\end{array}$ & $\begin{array}{l}\text { S. } \\
\text { D }\end{array}$ & $\begin{array}{l}\text { Mea } \\
\mathrm{n}\end{array}$ & $\begin{array}{l}\text { S. } \\
\text { D }\end{array}$ & $\begin{array}{l}\mathrm{Me} \\
\text { an }\end{array}$ & $\begin{array}{l}\text { S. } \\
\text { D }\end{array}$ & $\begin{array}{l}\text { Mea } \\
n\end{array}$ & S.D & $\begin{array}{l}\text { Mea } \\
n\end{array}$ & $\begin{array}{l}\text { S. } \\
\text { D }\end{array}$ \\
\hline Male & 160 & 4.1 & .05 & 4.4 & .05 & 4.2 & .05 & 4.2 & .05 & 4.1 & .06 & 4.3 & $\begin{array}{l}.0 \\
6\end{array}$ & 4.1 & .04 & 4.2 & $\begin{array}{l}.0 \\
4\end{array}$ \\
\hline $\begin{array}{l}\text { Fem } \\
\text { ale }\end{array}$ & 90 & 4.1 & .04 & 4.1 & .04 & 4.1 & .05 & 4.1 & .05 & 4.1 & .05 & 4.2 & $\begin{array}{l}.0 \\
5\end{array}$ & 4.0 & .03 & 4.1 & $\begin{array}{l}.0 \\
5\end{array}$ \\
\hline
\end{tabular}

The above results have been discussed first in the form of frequency distribution of respondents with respect to their demographic profile. Mean and S.D of responses of variables includes empowerment, professional development, skill development, vision \& mission, consistency in policies, agreement, organizational learning and customer focus. These values show significant understanding of employee's empowerment and behaviors. However, regression is used for hypotheses testing of employee empowerment and organization culture which are as follows. 


\subsection{Hypothesis Testing with Simple linear Regression}

H1: Organizational culture values have a significant impact on employee empowerment.

Table 3

Model Summary

\begin{tabular}{|l|l|l|l|l|}
\hline Model & $R$ & R Square & Adjusted R Square & $\begin{array}{l}\text { Std. Error of the } \\
\text { Estimate }\end{array}$ \\
\hline 1 & $.683^{\mathrm{a}}$ & .466 & .455 & .52598 \\
\hline
\end{tabular}

a. Predictors: (Constant), customerfocus, agreement, consistency, orglearning, visionnmission

The $\mathrm{R}$ value is .683 , represents the modest correlation between the independent variables and dependent variable. The adjusted R Square value in this case is 0.455 . This tells us that the five IVs in our model account for $45.5 \%$ variance in the DV-employee empowerment.

Table 4

Coefficients

\begin{tabular}{|c|c|c|c|c|c|c|}
\hline \multirow{2}{*}{\multicolumn{2}{|c|}{ Model }} & \multicolumn{2}{|c|}{ Unstandardized Coefficients } & \multirow{2}{*}{\begin{tabular}{|l}
$\begin{array}{l}\text { Standardized } \\
\text { Coefficients }\end{array}$ \\
Beta
\end{tabular}} & \multirow[b]{2}{*}{$\mathrm{t}$} & \multirow[b]{2}{*}{ Sig. } \\
\hline & & B & Std. Error & & & \\
\hline \multirow[t]{6}{*}{1} & (Constant) & .732 & .306 & & 2.391 & .018 \\
\hline & visionnmission & .046 & .245 & .035 & .188 & .005 \\
\hline & consistency & .600 & .080 & .543 & 7.474 & .000 \\
\hline & agreement & .024 & .129 & .026 & .185 & .030 \\
\hline & orglearning & .128 & .125 & .104 & 1.025 & .021 \\
\hline & customerfocus & .116 & .166 & .102 & .698 & .049 \\
\hline
\end{tabular}

a. Dependent Variable: empowerment

The hypothesis is that organization culture values have a significant impact on employee empowerment i.e., the beta coefficient is not different from zero. The $p$-value for beta coefficient of Vision/Mission is 0.005, Consistency in Policies is 0.000, Agreement is 0.030, Organization Learning is 0.021 , and Customer Focus is 0.049 . All these values are significant at $05 \%$ significance level. Thus we accept the hypothesis that organization culture values have significant impact on employee empowerment.

Hence and the regression equation will be as follow.

Employee Empowerment $=0.732+(.046)($ vision $)+(.600)($ policies consistency $)+(0.024)$ $($ agreement $)+(.128)$ (org. learning) $+(.116)$ (customer focus) 
H2: Organizational culture values have a significant impact on employee professional development.

Table 5

Model Summary

\begin{tabular}{|l|l|l|l|l|}
\hline Model & $R$ & R Square & Adjusted R Square & $\begin{array}{l}\text { Std. Error of the } \\
\text { Estimate }\end{array}$ \\
\hline 1 & $.795^{\mathrm{a}}$ & .791 & .790 & .19239 \\
\hline
\end{tabular}

a. Predictors: (Constant), customerfocus, agreement, consistency, orglearning, visionnmission

The $\mathrm{R}$ value is .795 , represents the high correlation between the independent variables and dependent variable. The adjusted $\mathrm{R}$ Square value in this case is 0.79 . This tells us that the five IVs in our model account for $79 \%$ variance in the DV-employee professional development.

Table 6

Coefficients

\begin{tabular}{|c|c|c|c|c|c|c|}
\hline \multirow{2}{*}{\multicolumn{2}{|c|}{ Model }} & \multicolumn{2}{|c|}{ Unstandardized Coefficients } & \multirow{2}{*}{\begin{tabular}{|l}
$\begin{array}{l}\text { Standardized } \\
\text { Coefficients }\end{array}$ \\
Beta
\end{tabular}} & \multirow[b]{2}{*}{$\mathrm{T}$} & \multirow[b]{2}{*}{ Sig. } \\
\hline & & $\mathrm{B}$ & Std. Error & & & \\
\hline \multirow[t]{6}{*}{1} & (Constant) & .024 & .112 & & -.211 & .833 \\
\hline & visionnmission & .129 & .090 & .113 & 1.441 & .015 \\
\hline & consistency & .211 & .029 & .219 & 7.207 & .000 \\
\hline & agreement & .089 & .047 & .112 & 1.889 & .060 \\
\hline & orglearning & .798 & .046 & .739 & 7.471 & .000 \\
\hline & customerfocus & .460 & .061 & .464 & 7.581 & .000 \\
\hline
\end{tabular}

a. Dependent Variable: profdev

The hypothesis is that organization culture values have a significant impact on employee professional development i.e., the beta coefficient is not different from zero. The $p$-value for beta coefficient of Vision/Mission is 0.015 , Consistency in Policies is 0.000 , Agreement is 0.060 , Organization Learning is 0.000 , Customer Focus is 0.000. All these values are significant at $05 \%$ significance level. Thus we accept the hypothesis that organization culture values have significant impact on employee professional development.

Hence and the regression equation will be as follow.

Employee Professional Development $=0.024+(.129)($ vision $)+(.211)$ (policies consistency) $+(0.089)$ (agreement) $+(.798)$ (org. learning) $+(.460)$ (customer focus)

H3: Organizational culture values have a significant impact on employee skill development. 
Table 7

Model Summary

\begin{tabular}{|l|l|l|l|l|}
\hline Model & $\mathrm{R}$ & R Square & Adjusted R Square & $\begin{array}{l}\text { Std. Error of the } \\
\text { Estimate }\end{array}$ \\
\hline 1 & $.761^{\mathrm{a}}$ & .723 & .721 & .16936 \\
\hline
\end{tabular}

a. Predictors: (Constant), customerfocus, agreement, consistency, orglearning, visionnmission

The $\mathrm{R}$ value is .761 , moderate correlation between the independent variables and dependent variable. The adjusted $\mathrm{R}$ Square value in this case is 0.761 . This tells us that the five IVs in our model account for $72 \%$ variance in the DV-employee skill development.

Table 8

Coefficients

\begin{tabular}{|c|c|c|c|c|c|c|}
\hline \multirow{2}{*}{\multicolumn{2}{|c|}{ Model }} & \multicolumn{2}{|c|}{ Unstandardized Coefficients } & \multirow{2}{*}{\begin{tabular}{|l} 
Standardized \\
Coefficients
\end{tabular}} & \multirow[b]{2}{*}{$\mathrm{t}$} & \multirow[b]{2}{*}{ Sig. } \\
\hline & & B & Std. Error & & & \\
\hline \multirow[t]{6}{*}{1} & (Constant) & .022 & .099 & & -.219 & .827 \\
\hline & visionnmission & .803 & .079 & .724 & 7.157 & .000 \\
\hline & consistency & .122 & .026 & .131 & 7.436 & .000 \\
\hline & agreement & .255 & .042 & .330 & 7.129 & .000 \\
\hline & orglearning & .080 & .040 & .076 & 1.979 & .049 \\
\hline & customerfocus & .099 & .053 & .103 & 3.081 & .003 \\
\hline
\end{tabular}

a. Dependent Variable: skilldev

The hypothesis is that organization culture values have a significant impact on employee skill development i.e., the beta coefficient is not different from zero. The $p$-value for beta coefficient of Vision/Mission is 0.000 , Consistency in Policies is 0.000 , Agreement is 0.000 , Organization Learning is 0.049 , Customer Focus is 0.003 . All these values are significant at $05 \%$ significance level. Thus we accept the hypothesis that organization culture values have significant impact on employee skill development.

Hence and the regression equation will be as follow.

Employee Professional Development $=0.022+(.803)($ vision $)+(.122)$ (policies consistency) $+(0.255)$ (agreement) $+(.080)$ (org. learning) $+(.099)$ (customer focus)

\section{DISCUSSION}

This study has analyzed the impact of organizational culture on employee career progression. Extensive literature review in this study shows that organizational culture impacts on career progression in different dimension depending on what cultural practices are associated with the 
organization. Strong organizational culture facilitates in smooth functioning of organization and affects its performance and employee's performance.

Organization culture supports career progression because employee cannot succeed on their own and career development initiatives must be employee-driven and also supported by the culture of the organization, not employee-exclusive. Rasool (2012) points out that effective manager have the knowledge of employees and support career developments which are aligned with employees' goals. Rasool (2012) concludes that the culture of the organization plays an important role in terms of employee's career advancement. Meglino (1989) suggests that organization values adopted by the employees contribute towards improvement of performance, particularly in profit organization.

Measurement of organization culture and its impact on employee career progression proved to be true. Tlaiss and Kauser (2010) in their finding discovered that the employees perceive their career progression to be affected by organizational culture, practices and networks, while monitoring and tokenism were shown to be less critical. The researchers in same study perceived that organizational value systems and norms are powerful determinant for career progression.

This study revealed that culture is the powerful element that shapes employee's work environment, work relationship and work process

\section{CONCLUSION}

Culture of an organization is shaped by its characters i.e. mission, goals, and values. It is most important that how these characters effect the culture and work situation to both organization and employees behaviors. As stated earlier in this study, these values and ways of behavior are capable of affecting the career progression of employees. Organization culture is an essential part of organization success. Results of regression model presented in this study show significant impact of organizational culture on employee career progression. Relationship of each culture variable with employee career progression shows significant evidence of positivity. In the same way strong culture promotes \& facilitates committed employees in an organization. Consequently, they put their maximum efforts so that organization can achieve its targeted goals. It can be concluded that organization culture has an impact on employee career progression, which ultimately leads them to better function and perform.

\section{REFERENCES}

Abosede, A. J. (2000). Samples and Sampling Methods. Abeokuta: Delbe Publishers.age. Career Development International. Vol. 15, No. 1, pp. 4-19.

Bellou, V. (2010). Organizational culture as predictor of job satisfaction: the role of gender

Chinelo, G.O. and Guy, C.I. (1996). Fundamentals of Research Methods. Enugu: Optimal Publishers.

Cletus, C.O. (2001). Foundations of Educational and Behavioural Research: Issues and Methodology. Benin City: Union Publishers. 
Organizational Culture and its Impact on Employee Career Progression in Public Sector Organizations in Pakistan

Denison, D.R. (1990). Corporate Culture and Organizational Effectiveness. New York: Wiley. Ejiogu, Aloy (2003). Issues in the Management of Public Institutions, Lagos, Nigeria: Pumark Executing Strategy: The Quest for Competitive Advantage. New York: McGraw-Hill.

Jones, M.O., Moore, M.D., and Snyder, R.C. (Eds.). (2009). Inside organizations. Thousand Karai, E.M. (2012). Perceived organizational barriers to women career progression in Kenya's Civil Service. International Journal of Advances in Management and Economics. Vol. 1, No. 6, pp. $23-45$.

Kunda, G. (1992). Engineering culture. Philadelphia, PA: Temple University Press.

Lewis, G. (1990). Corporate strategy in action: The strategy process in British road services.

London: Routledge.

Martin, J. (2002). Organizational culture: Mapping the terrain. Thousand Oaks, CA: Sage.

Meglino M., Kanungo N.R., (1996). Impact of Culture on Performance Management in developing countries. International Journal of Manpower. Volume: 17, Issue 4/5. Page 65-75

Miller, V.L. (2004). An examination of contemporary marketing prospects used by organizations

Mitroff, I.I. and Kilmann, R.H. (1995). "Stories that managers tell: A new tool for organizational problem solving”. Management Review, 64 (7),PP. 18-28.

Mitroff, I.I. and Kilmann, R.H. (2001). On Organizational Stories: Approach to the design and analysis of organizations through myths and stories. In R.H. Kilmann, L.R. Pondy, and L. Steven (Eds.), The Management of Organization Design. New York: Elsevier.

Nazir, N.A. (2011). The impact of organizational culture on corporate effectiveness: A study of the cement manufacturing industry in Nigeria. Unpublished PhD. Thesis, Department of Business Management, Benue State University, Markurdi, Benue State, Nigeria.

Nongo, E.S. and Ikyanon, D.N. (2012). The influence of corporate culture on employee commitment to the organization. International Journal of Business and Management. Vol. 7, No. 22, pp. 323.

Ogbor, J. O. (2003). “Corporate Culture as Corporate Hegemony”. Journal of Critical Management Studies, Vol. 23, No. 4, pp. 1-23.

Ogbor, J.O. (2012). Corporate Culture and Corporate Responsibility. New York: Crown Educational Publishers (Forthcoming).

Omokhudu, O.S. (2004). Understanding Public and Local Government Administration. Benin City, Nigeria: Ogbas Nig, Enterprise.

Pettigrew, A. M. (2003). “On studying organizational cultures”. Administrative Science Quarterly, 24, 570-581.

Pondy, L.R., Frost, P.J., Morgan, G., \& Dandridge, T. (Eds.), (1990). Organizational Symbolism, Greenwich, CT: JAI Press. Prentice Hall.

Schein, E. (2004). Organizational Culture and Leadership, New York: Wiley.

Sorensen, J.B.(2006). "The strength of corporate culture and the reliability Symbols and artifacts. New York: Walter de Gruyter

Thompson, A.A., Strickland, A.J. and Gamble, J.E. (2010). Crafting and

Trice, H.M., and Beyer, J.M. (1993). The cultures of work organizations, Englewood Cliffs, NJ:

Wilkins, A. L. (1989). Developing corporate character, San Francisco, CA: Jossey-Bass. with different culture types: A test of the convergence thesis in the US and Cote d' Ivoire. 
Unpublished PhD. Thesis, Robinson College of Business, Georgia State University, Atlanta, Georgia. 